2-29-2008

\title{
The Gentleman from Hagerstown: How Maryland Jews Won the Right to Vote
}

Kenneth Lasson

University of Baltimore School of Law, klasson@ubalt.edu

Follow this and additional works at: http://scholarworks.law.ubalt.edu/all_fac

Part of the Civil Rights and Discrimination Commons, Election Law Commons, Law and Politics Commons, Legal History Commons, and the Religion Law Commons

\section{Recommended Citation}

The Gentleman from Hagerstown: How Maryland Jews Won the Right to Vote, Baltimore Jewish Times, February 29, 2008

This Editorial is brought to you for free and open access by the Faculty Scholarship at ScholarWorks@University of Baltimore School of Law. It has been accepted for inclusion in All Faculty Scholarship by an authorized administrator of ScholarWorks@University of Baltimore School of Law. For more information, please contact snolan@ubalt.edu. 
sh's Journey b. $19^{\circ}$

\$1.25 February 29, 2008/Adar I 235768

hent Bill Hits n Annapolis

Recalls Baltimore's tic Moment
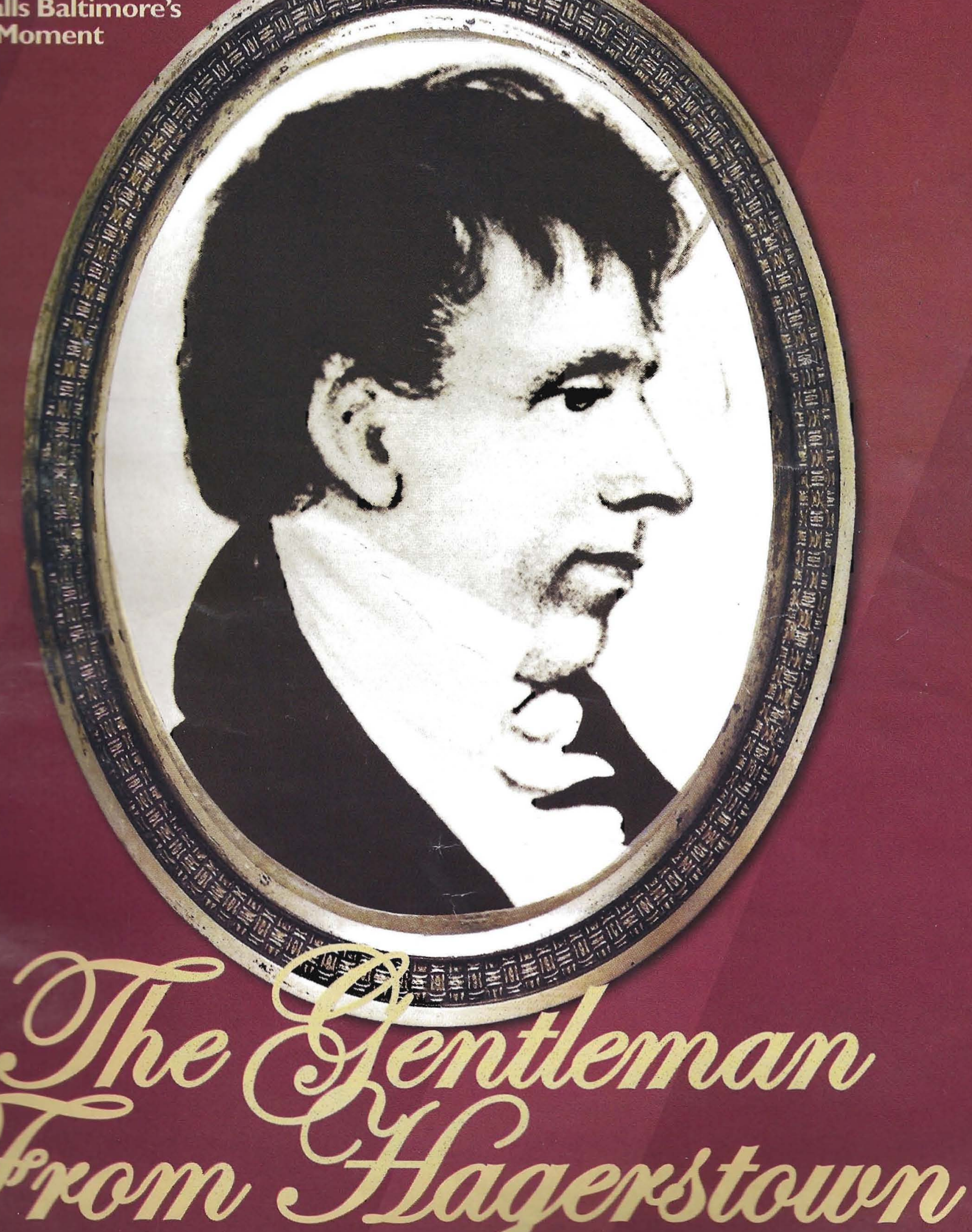

How Maryland Jews wobche right to vote 


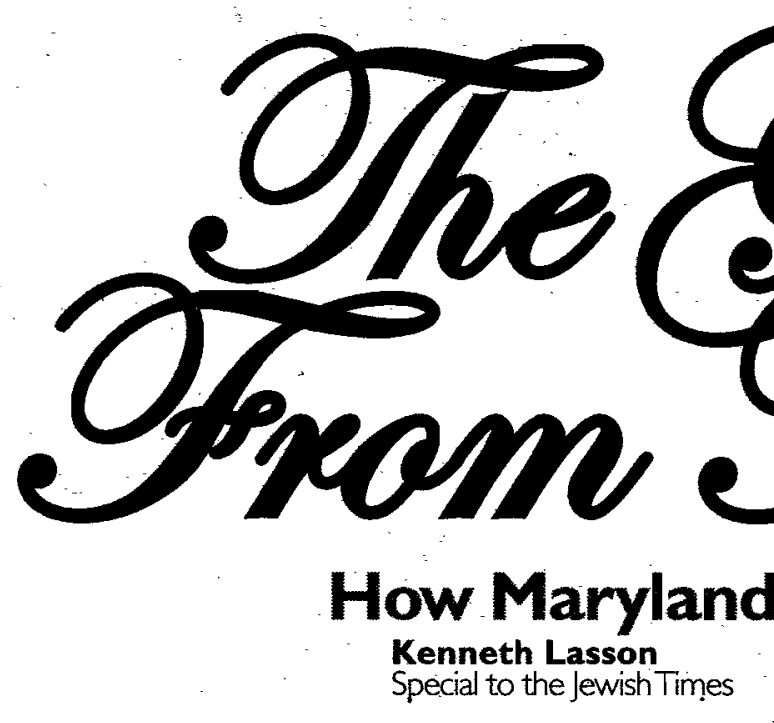

Faint not ye children of Israel; though cast down, ye shall never be destroyed, persecuted shall never be utterly forsaken; the hour of your deliverance approaches; and he who led 1 . fathers through the wilderness ... will ere long restore you to the promised land.

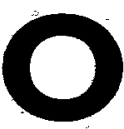

$\mathrm{n}$ a pleasant Saturday afternoon in late February of $1825-183$ years ago this week - the Jewish residents of Maryland could finally celebrate their full civil liberties as firstclass citizens.

Before that date, they had been prohibited from voting or holding public office, a circumstance that strikes the modern mind as inconceivably un-American.

For almost two centuries after the fledgling colony of Maryland was founded as a haven from religious persecution, and a full 50 years following the Declaration of Independence, only those professing a belief in Christianity could participate in elections and serve in the state government.

This is the story of the long and arduous struggle to achieve religious equality in Maryland, a campaign led largely by a gentile legislator with a.gift for passionate oratory, a remarkable man representing a small western county who claimed not to have "the slightest acquaintance with any Jew in the world.":

\section{Lumbrozo's Laugh}

Maryland was established in 1634, by and for George Calvert under a grant from King Charles I of England.

Kenneth Lasson, a law professor at the University of Baltimore who specializes in civil liberties, is a frequent contributor to the BALTMORE JEWISH TIMES.
Although Calvert was a nobleman, the first Lord Baltimore had been persecuted as a Catholic.

Calvert intended his colony to be a refuge for his fellow faithful, but he was also a man of peaceful aspirations, determined to make his stewardship neutral toward religion. When the first colonists landed on the shores of the southern Chesapeake at what was to become St. Mary's City, they purposefully set out to build a chapel and a state house on opposite ends of the town, thereby symbolizing the then-totally new concept of separating church and state.

Calvert carefully instructed his hand-picked governor not to offend the surrounding Protestant majority. Masses were to be celebrated in private; non-Catholics were to be treated "with as much mildness and favor as Justice will permit."

In 1649, Calvert promulgated an "Act Concerning Religion" in his General Assembly under which no form of Christianity was to be exalted over any other. The bill was hailed broadly as a beacon of religious liberty, and became known as the "Act of Toleration," an irony not immediately understood because it placed Catholics on an equal footing with Protestants. But anyone who would "blaspheme God ... or deny our Savior Jesus Christ to be the son of God, or shall deny the Holy Trinity ... shall be punished with death and confiscation or forfeiture of all his or her lands and goods to the Lord Proprietary and his heirs."

As it happened, one of the first people tried under the Act of Toleration - in ago - was a Jewish plyy New World in search of $?^{\text {? }}$ him to practice his faith t

\section{Solomon Etting}




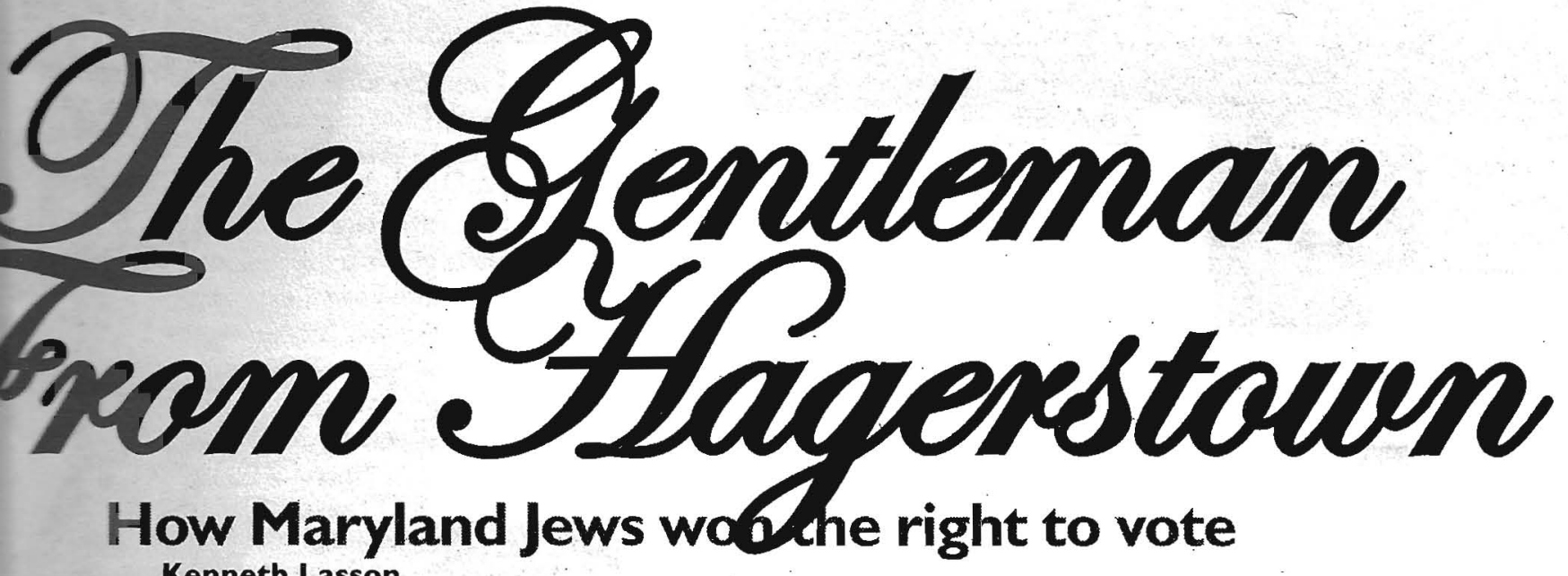

Kenneth Lasson

Special to the Jewish Times

aint not ye children of Israel; though cast down, ye shall never be destroyed, persecuted, ye

Il never be utterly forsaken; the hour of your deliverance approaches; and he who led your fathers through the wilderness ... will ere long restore you to the promised land.

- Thomas Kennedy, Annapolis, 1818

Ey afternoon in late

- 183 years ago this h residents of Maryland full civil liberties as first-

A been prohibited

ic office, a circumstance d as inconceivably

fer the fledgling colony a haven from religious is following the Declathose professing a articipate in elections. ment.

g and arduous struggle - Maryland, a campaign cor with a gift for pasman representing a aimed not to have "the vy Jew in the world." g Charles I of England.

The Uhiversity of Baltimore fequent contributor to the
Although Calvert was a nobleman, the first Lord Baltimore had been persecuted as a Catholic.

Calvert intended his colony to be a refuge for his fellow faithful, but he was also a man of peaceful aspirations, determined to make his stewardship neutral toward religion. When the first colonists landed on the shores of the southern Chesapeake at what was to become St. Mary's City, they purposefully set out to build a chapel and a state house on opposite ends of the town, thereby symbolizing the then-totally new concept of separating church and state.

Calvert carefully instructed his hand-picked governor not to offend the surrounding Protestant majority. Masses were to be celebrated in private; non-Catholics were to be treated "with as much mildness and favor as Justice will permit."

In 1649, Calvert promulgated an "Act Concerning Religion" in his General Assembly under which no form of Christianity was to be exalted over any other. The bill was hailed broadly as a beacon of religious liberty, and became known as the "Act of Toleration," an irony not immediately understood because it placed Catholics on an equal footing with Protestants. But anyone who would "blaspheme God ... or deny our Savior Jesus Christ to be the son of God, or shall deny the Holy Trinity ... shall be punished with death and confiscation or forfeiture of all his or her lands and goods to the Lord Proprietary and his heirs."

As it happened, one of the first people tried under the Act of Toleration - in 1658, exactly 350 years ago - was a Jewish physician who came to the New World in search of a place that would allow him to practice his faith more freely.

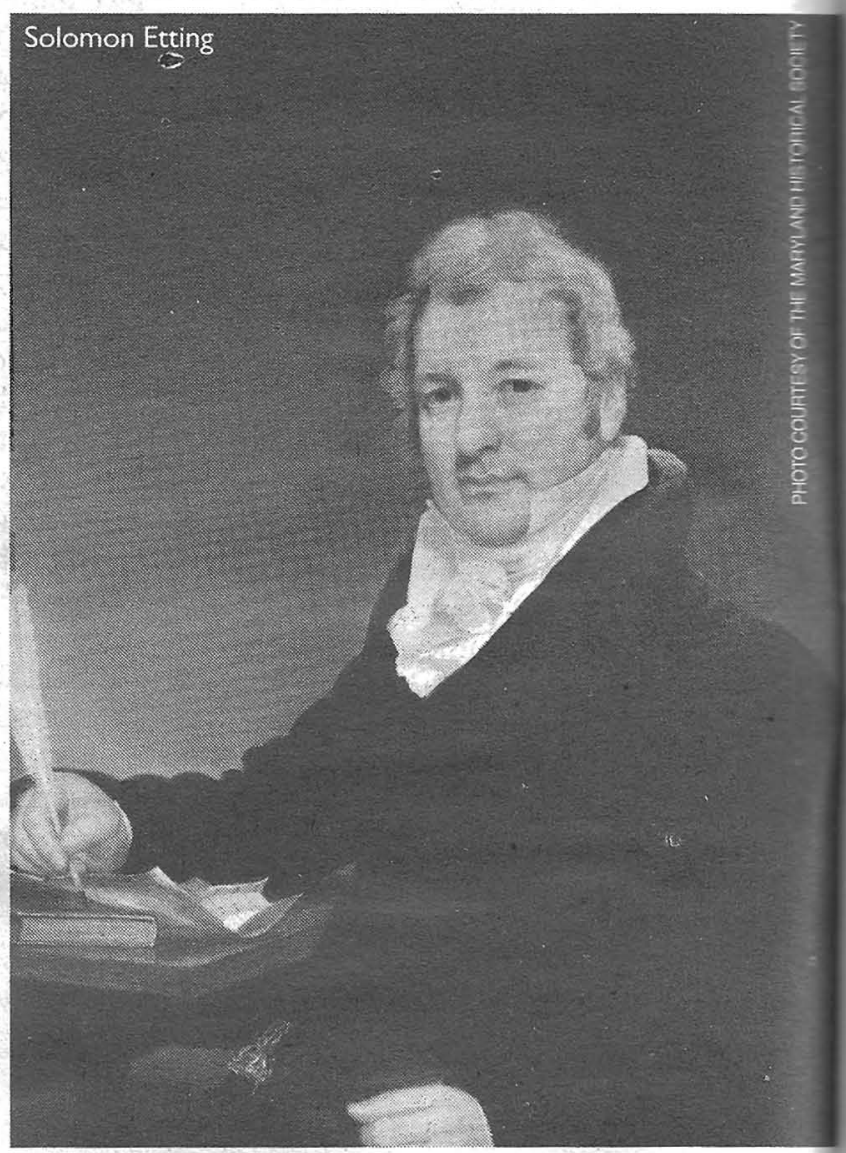


Jacob Lumbrozo had sailed to the colony from Portugal two years earlier. In Lisbon, he had lived as a Christian; Maryland, he thought, would provide a more congenial atmosphere. But a short time after his arrival, Lumbrozo found himself in a pub debating religion with a proselytizing Quaker named Josiah Coale.

Witnesses testified that when Coale asked, "Who was crucified at Jerusalem?” Lumbrozo replied, "A man." And how did this man perform his miracles? "By the art of magic." And the resurrection? Lumbrozo speculated that disciples probably stole the corpse. Lumbrozo was formally charged with committing blasphemy.

At the ensuing trial, another witness accused him of calling Jesus a "necromancer," to which, according to the court's transcript notes,

"Lumbrozo answered nothing but laughed." He was summarily convicted.

Perhaps it was a divine act that spared Lumbrozo the death penalty, for just then, the governor of Maryland, celebrating the accession of Oliver Cromwell as Lord Protector of England, issued a pardon to all who "stood indicted, convicted or condemned to die."

The case against Lumbrozo was dropped.

Although the penalties for blasphemy were later modified (a tongue-boring for the first offense, a branded "B" on the forehead for the second, death for the third), no other Jews were charged with blasphemy after Lumbrozo, and indeed no Marylander of any religion was ever put to death for the crime.

But it took almost 200 years after the founding of Maryland as a haven from religious persecution before Jews would achieve their full civil liberties.

\section{'Same Footing'}

In 1776, Maryland adopted its first constitution, which provided that "no other test or qualification ought to be required, on admission to any office of trust or profit, than such oath of support and fidelity to this State, and such oath of office, as shall be directed by this Convention or the Legislature of this State, and a declaration of a belief in the Christian religion."

More than 20 years passed before that restriction was challenged. In 1797, a petition signed by Solomon Etting and others was presented to the General Assembly at Annapolis. Etting had fought in the Revolution and was in public life in Pennsylvania before moving to Baltimore.

He was the first American-born schochet, or ritual slaughterer, and was one of the founders and a director of the Baltimore \& Ohio Railroad Co.

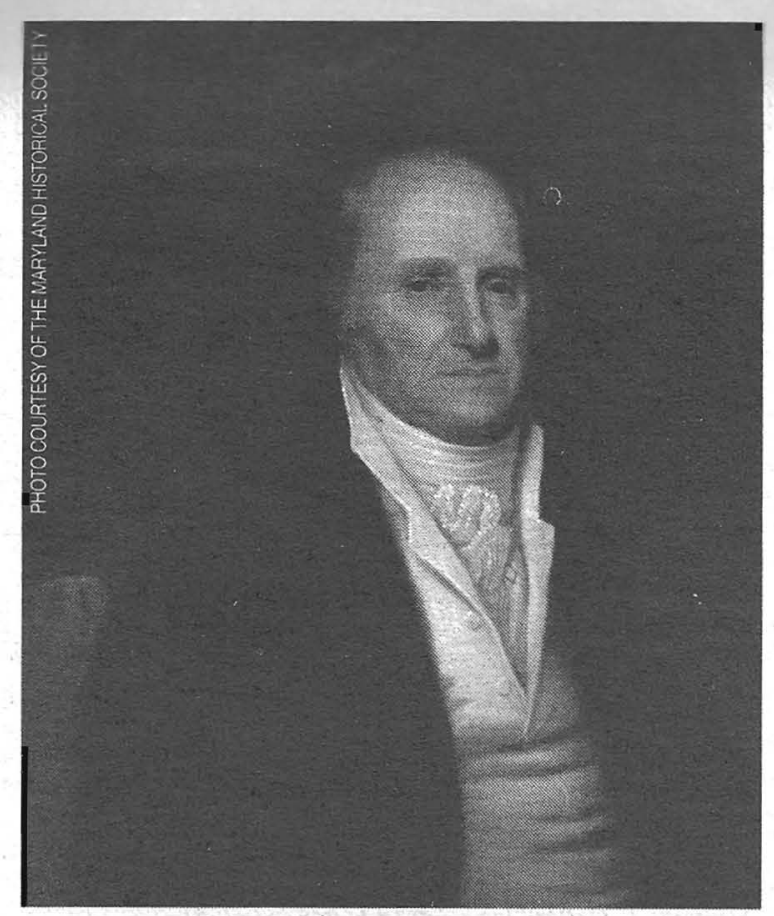

The sponsors averred that they were "a sect of people called Jews, and thereby deprived of many of the valuable rights of citizenship, and pray to be placed upon the same footing with other good citizens."

The petition was referred to a committee, which on the same day reported that although the request was "reasonable,".it involved a constitutional question of such considerable importance that it would be inappropriate to submit to the House "at this advanced" stage of the session.' This summary disposition of the matter put it to rest for the next five years.

In November 1802, another petition, this one specifically stating that Jews were "deprived of holding any office of profit and trust under the constitution and laws of this state," was sent to the General Assembly. A month later, it was rejected by a vote of 38-17. Similar bills were introduced the following two years; both likewise failed.

In 1803, the six sons and widow of Israel J. Cohen, who had been a magistrate and member of the city council in Richmond, moved to Baltimore. The eldest son became a successful businessman and banker, in the process cultivating relationships with important public figures of the time. But Jacob Cohen chafed under the political restrictions that dishonored his fellow Jewish citizens, especially those who had fought in the defense of Baltimore during the War of 1812 .

His religion barred him from accepting a captaincy in the local militia, as it had his friend Solomon Etting's son from gaining admission to the Maryland bar.

Beginning in 1816, Cohen pressed for a remedy to this inequity. The so-called "Jew Bill" became a controversial issue in Maryland politics, and attracted attention in other parts of the country as well. The popular press - from the Natchez (Miss.) Independent to the Sheperdstown (Va.) Eagle to the New York National Advocate - all denounced Maryland's discriminatory policy toward Jews.

In 1818, three of the Founding Fathers themselves - Thomas Jefferson, John Quincy Adams and James Madison - all penned letters recognizing religious equality and decrying its denial land.The national press followe Weekly Register, a Baltimore-ba that was the most influential ar periodical of the time, whose ec had always been outspoken in $\mathrm{h}$

A few non-Jewish Marylan bothered by the inequity, amon Brackenridge, E. S.Thomas, G W. G. D.Worthington and Johr

But by far, the most vocife Kennedy, the delegate from $\mathrm{H}$ Washington County.

\section{Passion For Justic}

Thomas Kennedy was born in 1776 . He grew up reading rom the young American enterpris idealism. He vowed "to spend service for freedom's cause."

At 19, he sailed to Georgetc to work for the Potomac Navi Kennedy married a girl from $\mathrm{F}$ in Williamsport, just southwest Washington County. His passic published a book of original v "largely," according to his gran of his interest in religious freed

In 1817 , Kennedy was elect House of Delegates. At that tim about 150 Jews in Maryland. $F$ one, Kennedy said, but he was the injustice of excluding an es because of their beliefs. For hir question which rests, or ought and his Creator alone."

Although there were few Je States and very few in Marylar was only one - to that one, w

Thus, it came to pass that or gentleman from Hagerstown the state's Constitution with "a the sect of people professing th the same rights and privileges Christians" - rose to speak be of Delegates:

Perhaps I have, Mr. Speaker, [1 felt more of the effects of religious $p$ members of this House. I once had strict and undeviating Christian in tion, and who would not have inj wealth of worlds; yet that father wi wedded to the Presbyterian opinion have followed his 12 children to th of them turn Roman Catholic; a h 
to had sailed to the colony from searlier. In Lisbon, he had lived ryland, he thought, would provide amosphere. But a short time mbrozo found himself in a pub with a proselytizing Quaker

fed that when Coale asked,"Who rusalem?" Lumbrozo replied,"A id this man perform his miraImagic." And the resurrection? tred that disciples probably stole fozo was formally charged with hemy.

rial, another witness accused ts a "necromancer," to which, ourt's transcript notes,

ered nothing but laughed." He nvicted.

a divine act that spared Lumbrozo for just then, the governor of ring the accession of Oliver 1 Protector of England, issued a "stood indicted, convicted or

st Lumbrozo was dropped. penalties for blasphemy were later ue-boring for the first offense, a he forehead for the second, death other Jews were charged with umbrozo, and indeed no Marygion was ever put to death for

ost 200 years after the founding aven from religious persecution achieve their full civil liberties.

\section{ting}

d adopted its first constitution, hat "no other test or qualification red, on admission to any office of h such oath of support and fidelity such oath of office, as shall be Convention or the Legislature declaration of a belief in the

years passed before that restriction 1797, a petition signed by Solomon was presented to the General polis. Etting had fought in the vas in public life in Pennsylvania Baltimore.

American-born schochet, or ritual as one of the founders and a limore \& Ohio Railroad Co.

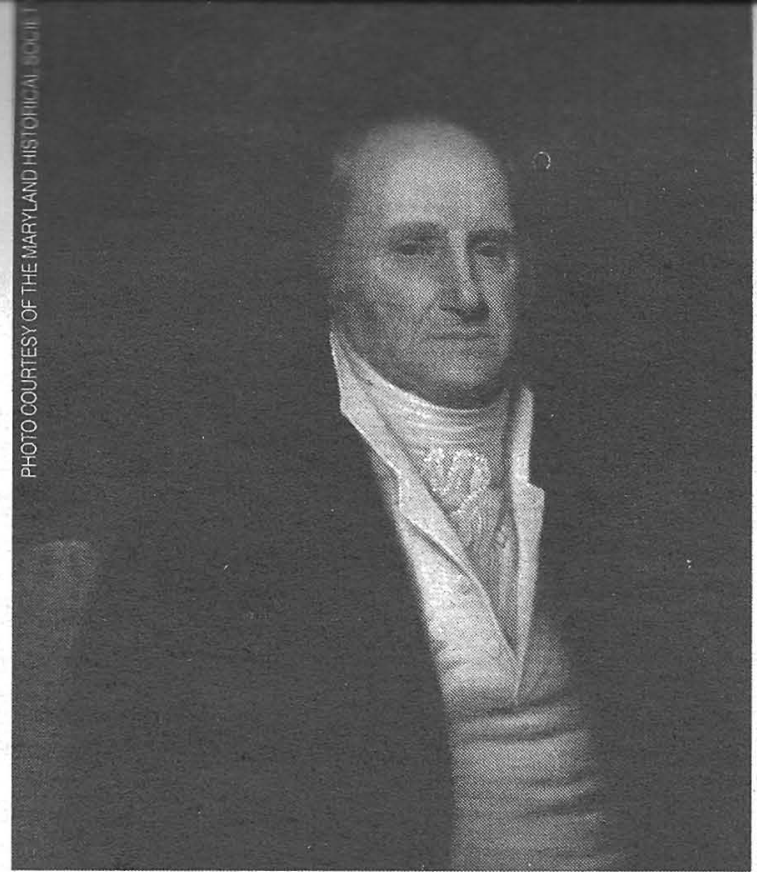

The sponsors averred that they were "a sect of people called Jews, and thereby deprived of many of the valuable rights of citizenship, and pray to be placed upon the same footing with other good citizens."

The petition was referred to a committee, which on the same day reported that although the request was "reasonable," it involved a constitutional question of such considerable importance that it would be inappropriate to submit to the House "at this advanced stage of the session."This summary disposition of the matter put it to rest for the next five years.

In November 1802, another petition, this one specifically stating that Jews were "deprived of holding any office of profit and trust under the constitution and laws of this state," was sent to the General Assembly. A month later, it was rejected by a vote of 38-17. Similar bills were introduced the following two years; both likewise failed.

In 1803, the six sons and widow of Israel J. Cohen, who had been a magistrate and member of the city council in Richmond, moved to Baltimore. The eldest son became a successful businessman and banker, in the process cultivating relationships with important public figures of the time. But Jacob Cohen chafed under the political restrictions that dishonored his fellow Jewish citizens, especially those who had fought in the defense of Baltimore during the War of 1812.

His religion barred him from accepting a captaincy in the local militia, as it had his friend Solomon Etting's son from gaining admission to the Maryland bar.

Beginning in 1816, Cohen pressed for a remedy to this inequity. The so-called "Jew Bill" became a controversial issue in Maryland politics, and attracted attention in other parts of the country as well. The popular press - from the Natchez (Miss.) Independent to the Sheperdstown (Va.) Eagle to the New York National Advocate — all denounced Maryland's discriminatory policy toward Jews.

In 1818, three of the Founding Fathers themselves - Thomas Jefferson, John Quincy Adams and James Madison - all pénned letters recognizing religious equality and decrying its denial to the Jews of Maryland.The national press followed the lead of Niles' Weekly Register, a Baltimore-based news magazine that was the most influential and widely quoted periodical of the time, whose editor, Hezekiah Niles, had always been outspoken in his defense of the Jews.

A few non-Jewish Maryland legislators were bothered by the inequity, among them Thomas Brackenridge, E. S.Thomas, General Winder, Col. W. G. D.Worthington and John V. L. MacMahon.

But by far, the most vociferous was Thomas Kennedy, the delegate from Hagerstown in Washington County.

\section{Passion For Justice}

Thomas Kennedy was born in Paisley, Scotland, in 1776. He grew up reading romantic descriptions of the young American enterprise, which stoked his idealism. He vowed "to spend my life in virtuous service for freedom's cause."

At 19, he sailed to Georgetown, where he went to work for the Potomac Navigation Co. In 1802, Kennedy married a girl from Frederick and settled in Williamsport, just southwest of Hagerstown in Washington County. His passions were poetry (he published a book of original verse) and politics "largely," according to his granddaughter," "because of his interest in religious freedom."

In 1817, Kennedy was elected to the Maryland House of Delegates. At that time, there were only about 150 Jews in Maryland. He had never met one, Kennedy said, but he was greatly disturbed by the injustice of excluding an entire group of people because of their beliefs. For him, religion was" a question which rests, or ought to rest, between man and his Creator alone."

Although there were few Jews in the United States and very few in Maryland, he said, "If there was only one - to that one, we ought to do justice."

Thus, it came to pass that on Jan. 20,1819 , the gentleman from Hagerstown - proposing to amend the state's Constitution with "an act to extend to the sect of people professing the Jewish religion the same rights and privileges that are enjoyed by Christians" - rose to speak before the. House of Delegates:

Perhaps I have, Mr. Speaker, [young as I am] seen and felt more of the effects of religious prejudice than most of the members of this House. I once had a father who was a strict and undeviating Christian in his ways and conversation, and who would not have injured his neighbor for the wealth of worlds; yet that father with all his piety, was so wedded to the Presbyterian opinions that he would rather have followed his 12 children to the grave, than seen one of them turn Roman Catholic; a hereditary hatred had 
subsisted for ages between those sects, and each of them too often used violent means in support of their doctrines.

Kennedy noted that John Calvin, father of Presbyterianism, had a man put to death for not believing in the Holy Trinity, and that Martin Luther thought it lawful to banish those whom he called heretics. He never expected to be so good a man as his father, he said, but having met many more Catholics and having found them "as amiable in all respects as the professors of other doctrines," his prejudice against them, if he ever had any, was at an end.

Kennedy then noted the ironies of Maryland's own religious history - including the falsely named Act of Toleration of 1649.

But even at this day, we have some sleeping statutes in Maryland, under which many of our most respectable citizens are liable to an ignominious establishment - nay even to death itself, if they honestly ... avow their religious opinions ... and it is our duty as legislators to guard against such a deplorable state of things by all the means within our delegated powers - we can do no better act for religion than to leave it free and unrestrained ... - and we can do no better act for Christianity, for it neither asks nor requires - nor authorizes civil governments to promote its cause.

He had surveyed the other states, Kennedy told his colleagues, and found that Maryland was the only place in the Union where Jews were still excluded from all offices, a fact, he said, that would certainly have offended the Founding Fathers:

And sir ... when they did form a Constitution under which this country has risen to greatness and glory, what

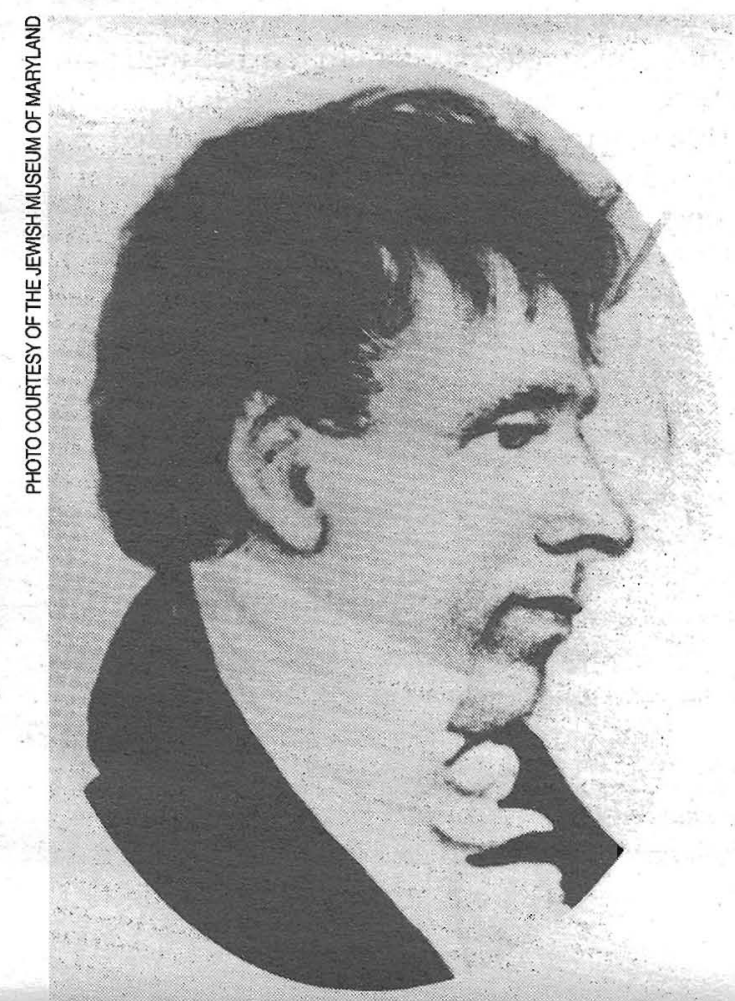

test or qualification did they declare ought to be required from those who were to guide the destinies of a great and rising empire. Merit, and merit alone, was the qualification required ... We all profess a regard for the character and principles of Washington - let us then walk in his path, and follow his truly Christian example.

Is it not strange, is it not absurd and ridiculous that a Jew should be denied every office under the state of Maryland, and yet be eligible to all offices under the Constitution of the United States? With us he cannot be a constable a justice of the peace - a practicing attorney, or an ensign in the militia; with them he may be a judge of the Supreme Court, hold a seat in Congress, command the armies of the United States, or even fill the presidential chair. Such strange inconsistencies ought to exist no longer.

Lest he be suspected of favoring Jews for personal reasons, Kennedy told his fellow legislators there were no Jews in his county, that he did not know any Jew personally, and that "it was not even known to them that the subject would be brought forward at this time."

He could not forbear offering a heartfelt plea:

Mr. Speaker, had I the tongue and the talents of a Cicero, or a Demosthenes... I could talk to you on this subject until the sun went down, and rose again... But perhaps it is well for the Jews that they have not such an advocate; you might in such a case distrust your sober senses; and fear that you were deceived, or imposed upon by his irresistible powers; it is well for the Jews that their cause needs not the aid of talents and eloquence; with truth and justice on their side, we need not fear the result, nor do I fear it. That the bill will pass I have no doubt, but I do not wish to see it pass by a casting vote, or by a lean majority; for the honor of Maryland, I wish to see it pass unanimously. I wish to see the votes all recorded upon one side - Affirmative, all - Negative, none.

Now even more passionate, Kennedy invoked biblical references:

Poor, hapless, unfortunate children of Israel, how are ye fallen! Once the peculiar people of God, and enjoying His favor, His protection, and His immediate presence; blest with a land flowing with milk and honey, with a climate bland as the dews of heaven, and a soil luxuriantly fertile; now scattered and dispersed, oppressed and persecuted, without a country and without a home. Ye have drank deep of adversity's bitter.draught; ye have indeed emptied 'the cup of trembling even unto the dregs' - yet scattered and dispersed as ye have been; amidst all your distresses and unparalleled sufferings - ye have still been faithful and true to the religion of your forefathers; ye have still wor-

A native of Paisley, Scotland, Thomas Kennedy grew up reading romantic descriptions of the young American enterprise, which stoked his idealism. He vowed "to spend my life in virtuous service for freedom's cause."

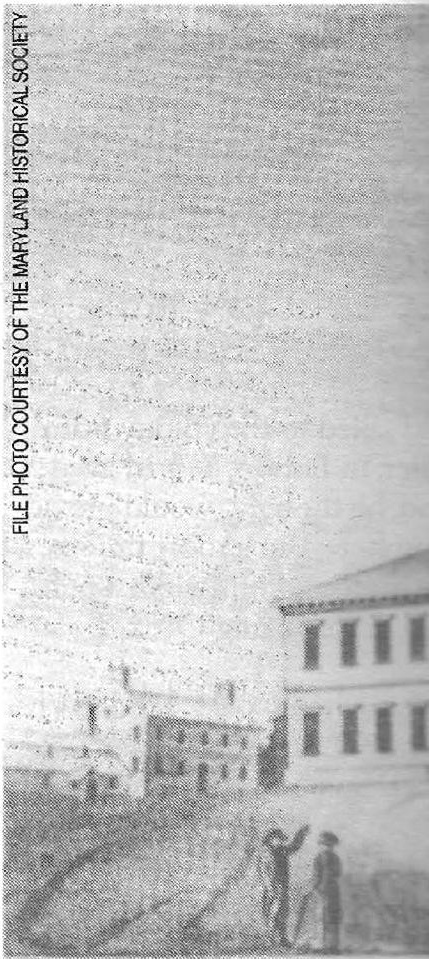

shipped the God of Abraham; an your destroyers destroyed. But fea faint not ye children of Israel; tho never be destroyed, persecuted, ye forsaken; the hour of your deliver of your redemption draweth nigh fathers through the wilderness, he served you as a nation - as a pu long restore you to the promised

It was not mere fairness fo pleading, he said, but justice:

Think not that I mean to sup use the tones of pity, in behalf of Mr. Speaker, I would not accept th on your table, in a boon or as a fa more independent grounds. I den tice, sheer justice, and whatever m uill always be a proud consolatio that there has been no intrigue, n. management used in its behalf.

And to the honor, to the prai we have not seen them busying t lobby, or waiting on us at our chat with a noble delicacy on the oma the passage of this bill at heart, if they cannot succeed openly and them to succeed at all.

Kennedy, having already hours, was spent:

Mr. Speaker, I will no longer and the patience of the members - and when I look around me nances beaming with benevolens moment that this bill will not pis Israel will be refused their just $r$ as men, who love to enjoy the fra opinions, to do them justice.

I call upon you as legislator. mitted the destinies of a free and them justice. I call upon you as what you would expect, what 1 
reen those sects, and each of them too in support of their doctrines. that John Calvin, father of d a man put to death for not Trinity, and that Martin vful to banish those whom he never expected to be so good a e said, but having met many having found them "as amiable professors of other doctrines," them, if he ever had any, was at

toted the ironies of Maryland's ry - including the falsely ation of 1649 .

Jy, we have some sleeping statutes in dh many of our most respectable citinominious establishment - nay they honestly ... avow their religious our duty as legislators to guard atle state of things by all the means ovuers - we can do no better act for is froe and unrestrained ... - and If for Christianity, for it neither asks horizes civil governments to pro-

A the other states, Kennedy told found that Maryland was the nion where Jews were still exces, a fact, he said, that would ded the Founding Fathers: hey did form a Constitution under 5 risen to greatness and glory, what

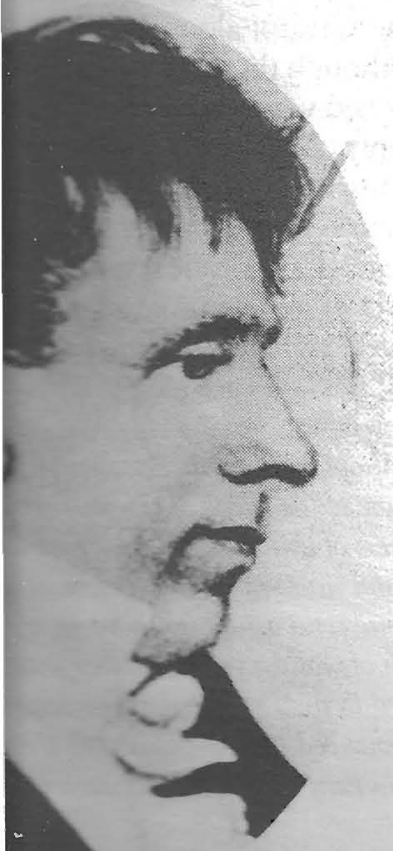

test or qualification did they declare ought to be required from those who were to guide the destinies of a great and rising empire. Merit, and merit alone, was the qualification required... We all profess a regard for the character and principles of Washington - let us then walk in his path, and follow his truly Christian example.

Is it not strange, is it not absurd and ridiculous that a Jew should be denied every office under the state of Maryland, and yet be eligible to all offices under the Constitution of the United States? With us he cannot be a constable a justice of the peace - a practicing attorney, or an ensign in the militia; with them he may be a judge of the Supreme Court, hold a seat in Congress, command the armies of the United States, or even fill the presidential chair. Such strange inconsistencies ought to exist no longer.

Lest he be suspected of favoring Jews for personal reasons, Kennedy. told his fellow legislators there were no Jews in his county, that he did not know any Jew personally, and that "it was not even known to them that the subject would be brought forward at this time."

He could not forbear offering a heartfelt plea:

Mr. Speaker, had I the tongue and the talents of a Cicero, or a Demosthenes... I could talk to you on this subject until the sun went down, and rose again... But perhaps it is well for the Jews that they have not such an advocate; you might in such a case distrust your sober senses, and fear that you were deceived, or imposed upon. by his irresistible powers; it is well for the Jews that their cause needs not the aid of talents and eloquence; with truth and justice on their side, we need not fear the result, nor do I fear it. That the bill will pass I have no doubt, but I do not wish to see it pass by a casting vote, or by a lean majority; for the honor of Maryland; I wish to see it pass unanimously. I wish to see the votes all recorded upon one side - Affirmative, all - Negative, none.

Now even more passionate, Kennedy invoked biblical references:

Poor, hapless, unfortunate children of Israel, how are ye fallen! Once the peculiar people of God, and enjoying His favor, His protection, and His immediate presence; blest with a land flowing with milk and honey, with a climate bland as the dews of heaven, and a soil luxuriantly fertile; now scattered and dispersed, oppressed and persecuted, without a country and without a home. Ye have drank deep of adversity's bitter draught; ye have indeed emptied 'the cup of trembling even unto the dregs' - yet scattered and dispersed as ye have been; amidst all your distresses and unparalleled sufferings - ye have still been faithful and true to the religion of your forefathers; ye have still wor-

A native of Paisley, Scotland, Thomas Kennedy grew up reading romantic descriptions of the young American enterprise, which stoked his idealism. He vowed "to spend my life in virtuous service for freedom's cause."

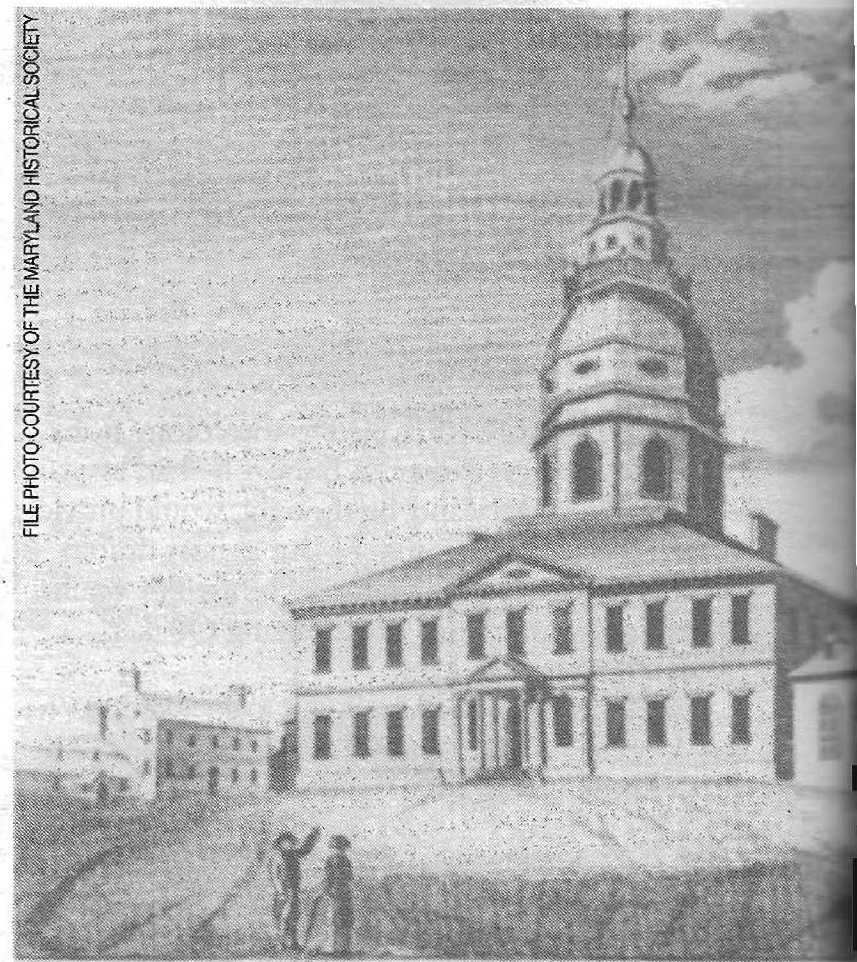

shipped the God of Abraham; and ye have lived to see your destroyers destroyed. But fear not ye sons of Jacobfaint not ye children of Israel; though cast doun, ye shall never be destroyed, persecuted, ye shall never be utterly forsaken; the hour of your deliverance approaches; the day of your redemption draweth nigh; and he who led your fathers through the wilderness, he who has hitherto preserved you as a nation - as a peculiar people, will ere long restore you to the promised land.

It was not mere fairness for which Kennedy was pleading, he said, but justice:

Think not that I mean to supplicate your mercy or to use the tones of pity, in behalf of these oppressed people; no, Mr. Speaker, I would not accept the passage of the bill now on your table, in a boon or as a favor - I take higher and more independent grounds. I demand it as an act of justice, sheer justice, and whatever may be the fate of the bill, it will always be a proud consolation to its friends, to think that there has been no intrigue, no out of doors influence, or management used in its behalf.

And to the honor, to the praise of the Jews be it spoken, we have not seen them busying themselves, crowding our lobby, or waiting on us at our chambers; they have acted with a noble delicacy on the occasion, and much as I have the passage of this bill at heart, much as I lament their fate, if they cannot succeed openly and honorably, I do not wish them to succeed at all.

Kennedy, having already spoken for several hours, was spent:

Mr. Speaker, I will no longer trespass upon the time and the patience of the members of this honorable House - and when I look around me and see so many counte nances beaming with benevolence, I cannot think for a moment that this bill will not pass, or that the children of Israel will be refused their just rights; and I call upon you, as men, who love to enjoy the free exercise of your own opinions, to do them justice.

I call upon you as legislators, to whose hands are committed the destinies of a free and generous people, to do them justice. I call upon you as Christians, to consider what you would expect, what you would ask, were you 


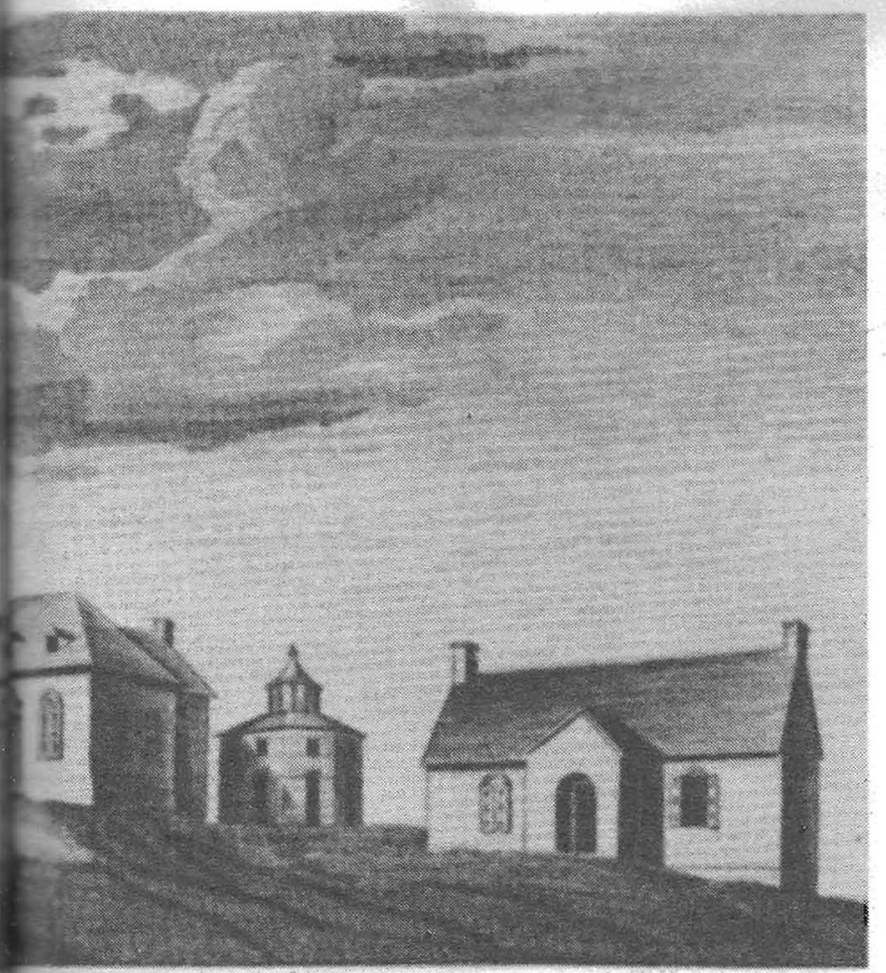

now in their situation - and to do them justice, do them justice. I ask no more.

Kennedy sat down. A delegate from Montgomery County made a short speech in reply, opposing the bill. The proposal would permit even atheists to hold public office, and as such was far too liberal. Judge H.M. Brackenridge, an erudite delegate from Baltimore City, advocated strongly and at great length in favor of the measure.

The debate went on for several more days.

In the end, the bill failed, by a vote of 50-24.

Kennedy pledged himself to renew the fight. The following year, he reintroduced the bill; it was again defeated by a wide margin.

In 1822 , the bill passed the Senate. When it came to the House, Kennedy once again spoke passionately on its behalf:

What does our test law say to the Hebrews: It tells them that they shall perform all the duties, and bear all the burdens of citizens without enjoying common privileges.... We tell them your son may be all that is wise and good, he may take the first honors at school ... let him be as wise and patriotic as Washington, he never can represent the people in the legislature, or command them in the militia: ... This bill ought to pass even if it was only to do justice to the long oppressed Hebrew; but it is not for their benefit alone; it is establishing a general principle ... sanctioned by reason, by religion and by common sense ... approved by the patriots of the revolution, sanctioned by wisdom and virtue and tested by experience. ... Let us pass this bill ... even on a dying pillow it will comfort us to think that we have done at least one good act in our lives ... establishing religious freedom in Maryland. .

After a stirring debate, the "Jew Bill" once again went down to defeat.

By now, his efforts to secure religious liberty for the Jews had brought Kennedy a considerable amount of disgrace. In the election campaign of 1823, he was said to represent the "Jew ticket."

His opponent on the "Christian ticket" was Benjamin Galloway, who attacked Kennedy as a
"Judas Iscariot," "one half Jew and the other half not a Christian," and "an enemy of Christianity." Galloway, disclaiming the support of "Jews, Deists, Mohammedans, or Unitarians," won election to the Maryland House of Delegates by a large margin.

\section{Turning Tide}

The controversy continued over "Kennedy's Jew Baby," as the bill had come to be called.

Opponents argued that Kennedy's proposal would permit even atheists to hold public office, and as such was far too liberal. It was not limited to Washington County: in the general election of 1823 , out of 40 members who had voted in favor of the bill, only 16 were returned to the next assembly.

Even while out of office, Kennedy declared his intention to continue the fight: "Although exiled at home, I shall continue to battle for the measure, aye, until my last drop of blood."

By 1824, public and press opinion had now moved in favor of the measure in Baltimore, where most of the state's Jewish population resided, and even if the House of Delegates the bill by a bare majority, 26-2: choosing to be absent.

When the "Jew Bill" had at 1 Hezekiah Niles informed reade Register about "the political liber held in servitude for CONSCII late disgraceful part of our cons JEWS ARE FREE MEN."

The new law provided that " state professing the Jewish religi appointed to any office of profit dition to the required oaths, ma declaration of his belief in a futu and punishmients instead of the required by the government of requirement was dropped in 18

On Jan. 5, 1826, an enabling (by a vote of 45-32) that effectiv clauses in the state constitution holders to be Christians. In Oct Solomon Etting and Jacob I. C to the Baltimore City Council, the tide had begun to turn on the state level as well. Del.John Van Lear McMahon, in particular, joined the cause, delivering a powerful speech of five hours' length in support of the bill.

A year later, Kennedy ran for the House of Delegates again, this time as an independent, and was elected. His first order of business was to introduce another bill on behalf of the Jews. This time, the result was different.

On Saturday, Feb. 26, 1825 - almost two centuries after Maryland was founded as a haven of religious liberty and beacon of toleration, and six long years since Kennedy had begun his campaign - the General Assembly of Maryland grudgingly granted Jews their basic civil liberties. It was the last day of that year's legislative session.

Kennedy's quest "to relieve persons from political disqualifications on account of their religious opinions" had finally come to fruition - even if his eloquent plea for unanimity had fallen on deaf ears, voted into office in Maryland.

After passage of the "Jew Bab" to Hagerstown; where he becam helped to establish the Hagerston later edited. He served in the sta 1826 to 1831.

An epidemic of Asiatic chole of Thomas Kennedy, in October century after he first champione in Maryland, some citizens of $\mathrm{H}$ monument in his memory.

In 1995 , the speaker of the announced the establishment 0 Kennedy Award, to recognize exhibited "personal courage an principles of liberty and freedor

A plaque in Sinai Hospital of Kennedy as saying, "I pray to $\mathrm{G}$ I cease to be the friend of civil and a supporter of the rights of 


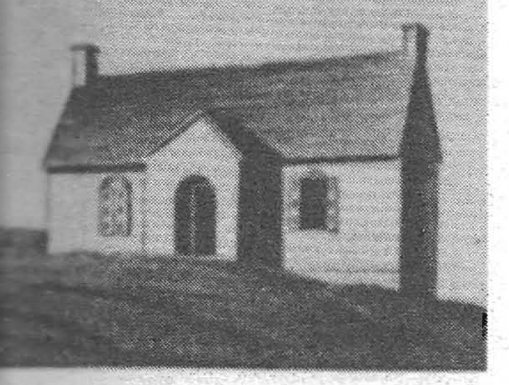

n- and to do them justice, do them

n. A delegate from Montgomery hort speech in reply; opposing the would permit even atheists to and as such was far too liberal. enridge, an erudite delegate from ocated strongly and at great the measure.

the on for several more days.

bill failed, by a vote of 50-24.

sed himself to renew the fight.

ar, he reintroduced the bill; it was a wide margin.

passed the Senate. When it came anedy once again spoke passion-

ast law say to the Hebrews: It tells perform all the duties, and bear all the ithout enjoying common privileges.... may be all that is wise and good, he mors at school... let him be as wise ington, he never can represent the are, or command them in the militia: pass even if it was.only to do justice to Hebrew; but it is not for their benefit g a general principle ... sanctioned by - d by common sense ... approved by tolution, sanctioned by wisdom and eqperience.... Let us pass this bill ... it will comfort us to think that we a good act in our lives ... establishing Marland. .

debate, the "Jew Bill" once again ean.

forts to secure religious liberty for the Kennedy a considerable In the election campaign of to represent the "Jew ticket." on the "Christian ticket" was ax, who attacked Kennedy as a
"Judas Iscariot," "one half Jew and the other half not a Christian," and "an enemy of Christianity." Galloway, disclaiming the support of "Jews, Deists, Mohammedans, or Unitarians," won election to the Maryland House of Delegates by a large margin.

\section{Turning Tide}

The controversy continued over "Kennedy's Jew Baby," as the bill had come to be called.

Opponents argued that Kennedy's proposal would permit even atheists to hold public office, and as such was far too liberal. It was not limited to Washington County: in the general election of 1823, out of 40 members who had voted in favor of the bill, only 16 were returned to the next assembly.

Even while out of office, Kennedy declared his intention to continue the fight: "Although exiled at home, I shall continue to battle for the measure, aye, until my last drop of blood."

By 1824, public and press opinion had now moved in favor of the measure in Baltimore, where most of the state's Jewish population resided, and even if the House of Delegates had voted to pass the bill by a bare majority, 26-25, with 29 legislators choosing to be absent.

When the "Jew Bill" had at long last succeeded, Hezekiah Niles informed readers of his Weekly Register about "the political liberation of persons held in servitude for CONSCIENCE SAKE, so a late disgraceful part of our constitution is absolved. JEWS ARE FREE MEN."

The new law provided that "every citizen of this state professing the Jewish religion who shall be appointed to any office of profit or trust shall, in addition to the required oaths, make and subscribe a declaration of his belief in a future state of rewards and punishments instead of the declaration now required by the government of the state." (This requirement was dropped in 1867.)

On Jan. 5, 1826, an enabling statute was passed (by a vote of 45-32) that effectively repealed the clauses in the state constitution requiring officeholders to be Christians. In October of that year, Solomon Etting and Jacob I. Cohen were elected to the Baltimore City Council, the first Jews ever

\section{Thomas Kennedy's opponent on the "Christian ticket" was Benjamin Galloway, who attacked him as a "Judas Iscariot," "one half Jew and the other half not a Christian," and "an enemy of Christianity."}

the tide had begun to turn on the state level as well. Del. John Van Lear McMahon, in particular, joined the cause, delivering a powerful speech of five hours' length in support of the bill.

A year later, Kennedy ran for the House of Delegates again, this time as an independent, and was elected. His furst order of business was to introduce another bill on behalf of the Jews. This time, the result was different.

On Saturday, Feb. 26, 1825 - almost two centuries after Maryland was founded as a haven of religious liberty and beacon of toleration, and six long years since Kennedy had begun his campaign - the General Assembly of Maryland grudgingly granted Jews their basic civil liberties. It was the last day of that year's legislative session.

Kennedy's quest "to relieve persons from political disqualifications on account of their religious opinions" had finally come to fruition - even if his eloquent plea for unanimity had fallen on deaf ears, voted into office in Maryland.

After passage of the "Jew Baby," Kennedy returned to Hagerstown, where he became postmaster and helped to establish the Hagerstown Mail, which he later edited. He served in the state Senate from 1826 to 1831.

An epidemic of Asiatic cholera claimed the life of Thomas Kennedy, in October 1832. In 1918, a century after he first championed the rights of Jews in Maryland, some citizens of Hagerstown erected a monument in his memory.

In 1995, the speaker of the House of Delegates announced the establishment of an annual Thomas Kennedy Award, to recognize legislators who have exhibited "personal courage and dedication to the principles of liberty and freedom."

A plaque in Sinai Hospital of Baltimore quotes Kennedy as saying, "I pray to God I may die before I cease to be the friend of civil and religious liberty, and a supporter of the rights of the people." 